原著

視運動刺激負荷重心動摇検査による評価

\begin{tabular}{|c|c|c|}
\hline 加藤 & 雅也 ${ }^{1)}$ • 伊藤 & 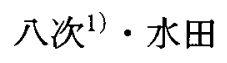 \\
\hline 久世 & 文也 $^{1)}$ - 宮田 & 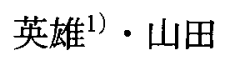 \\
\hline
\end{tabular}

\title{
Studies of Optokinetic Stimulus on Postural Control
}

\author{
Masaya Kato ${ }^{1)}$, Yatsuji Ito ${ }^{1)}$, Keisuke Mizuta ${ }^{1)}$, \\ Bunya Kuze ${ }^{1)}$, Hideo Miyata ${ }^{1)}$, Takahiro Yamada ${ }^{2)}$ \\ 1) Department of Otorhinolaryngology, Gifu University School of medicine \\ 2) Department of Otorhinolaryngology, JR Tokai Hospital
}

It is difficult to estimate individual performance in sports because of the complicated relationship of various reflexes, accommodation and mental state. To clarify that part of sports ability, we investigated the effect of horizontal optokinetic stimulus training on body balance.

Experiment A: Male subjects were stimulated optokinetically to the right on stabilometer. The angular velocity of the Ohm type drum was $60 \mathrm{deg} / \mathrm{sec}$ and the duration of the stimulation was 60 seconds. This training was conducted twice a day for 4 weeks. Before and during this training, we performed the test every week and then again after a rest period of 2 weeks. Total length, $\mathrm{x}$ part (stimulus direction) length, area of sway, locus length per limit area were calculated. These parameters decreased after 2 weeks and were maintained after a period of 2 weeks except for locus length per limit area.

Experiment B: Male subjects were trained as in experiment A and compared with high school baseball players. High school baseball players have a good control of balance as shown in the $\mathrm{x}$ part (stimulus direction) and locus length per limit area compared to those in male subjects.

Experiment C: Male subjects were stimulated optokinetically to the right while sitting on a chair and findings were compared to those in male subjects who served as control. The drum was rotated with an acceleration of $2 \mathrm{deg} / \mathrm{sec}^{2}$ and this training was conducted twice a day for 3 weeks. Before and after this training, we performed this test. We found out that training while seated on a chair stabilized body balance.

Key words: sports ability, optokinetic stimulus, stabilometer, body balance

1) 岐皁大学医学部耳鼻咽喉科学教室

2) JR 東海総合病院耳鼻咽喉科 


\section{はじめに}

訓練により平衡機能が向上することはよく知ら れている。Hoshino ${ }^{1)}$ は回転訓練により回転後眼 振の減少すること（response decline）を報告し た。時田 ${ }^{2)}$ は運動選手に和いて視運動性眼振の適 応の限界 (optokinetic adaptation limit, OAL) が高いことを報告し，戸村3)は視運動訓練による OAL の上昇を報告している。をた，運動能力を 評価する 1 つの指標に身体の安定性の良し悪しが ある。特に外乱を加光た場合に，身体の安定化を いかに計れるかといらことは運動能力の一面を表 していると思われる。近時，めまい.平衡障害例 の身体動摇を評価する方法として重心動摇検査が 普及して敊り，運動選手に対しても重心動摇検査 が利用されつつあるが，評価は未だ一定していな い。今回, 身体の安定さと運動能力の優秀さ（優 れた運動選手）を見いだすにはどのよらな検査が 適しているかを検討する目的で, 直立時身体動摇 に影響を及洼す視運動刺激を外乱として負荷し, その時の身体動摇を重心動摇検查を用いて評価す ることを試みた。第 1 に，一般健康男子に打いて 視運動刺激負荷時の重心動摇が訓練によりどのよ 5に変化するかる検討した。第 2 に, 運動能力の 高いと思われる高校野球選手に訓練なしでこの検 查を行い, 訓練を行った一般健康男子の結果と比 較検討した。第 3 に,この訓練における視器の影 響を検討した。

方法

A. 一般健康男子の視運動刺激負荷訓練による 重心動摇

一般健康男子を対象として, 視運動刺激負荷を
加竞た時に直立姿勢を保つ訓練を 4 週間行い，訓 練が身体の安定化 (訓練の獲得) にどのよらな効 果をもたらすかを視運動刺激負荷時の重心動摇で 検討した。また訓練休止 2 週後にこの検査を行 い, 訓練効果の維持を検討した。

\section{1) 被験者}

めまい・平衡障害の既往がなく、スポーツ選手 でない一般健康男子 5 名（25-35歳）である。

\section{2) 訓練方法}

内面に12本の線条が付してある直径 $1.5 \mathrm{~m}$, 高 さ $2 \mathrm{~m}$ の $\mathrm{Ohm}$ 型大円筒の中央に被験者を閉足で 直立させ，前方 $70 \mathrm{~cm}$ に設置した視標を固視さ せて打き，視運動刺激負荷を与えた（図 1)。視 運動刺激負荷は，等角速度 $60 \%$ sec，右回転のみ で，60秒間与えた。刺激中は頭部を正面に向かっ てまっすぐに保ち，頭部，軀幹を回旋させないよ うに努めさせた。上記条件で直立時の身体を安定 化させる訓練を, 1 日朝夕 2 回, 4 週間連日行。 た。

3）訓練効果の評価方法

a ) 訓練の獲得の評価

訓練に用いる $\mathrm{Ohm}$ 型大円筒の中央に重心動摇 計（日本電気三栄製 1G06）を置き，その上に被 験者を閉足で直立させ，訓練時と同様な条件で重 心動摇を記録した。重心動摇計からの出力をデー タレコーダーに記録し，シグナルプロセッサー(7 T17）で解析した。視運動刺激開始 10 秒後から 30 秒間の重心動摇の総軌跡長, 左右径, 外周面積, 単位面積軌跡長を検討した。また同時にひらめ筋 活動を表面電極で捉え，テレィーターを介してポ リグラフ記録した。訓練前, 訓練 1 週後, 訓練 2

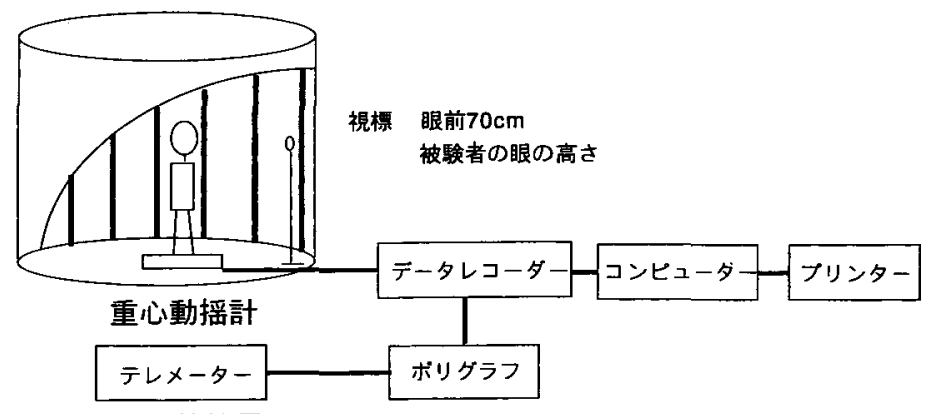

ひらめ筋筋電図

図 1 訓練と検査装置 
週後, 訓練 4 週後に評価を行った。

b）訓練効果の維持の評価

訓練効果の維持を検討するために，訓練休止を 2 週間行い，その後に同様な検査を行い評価し た。

B. 高校野球選手の視運動刺激負荷による重心 動摇

運動能力の高いと思われる高校野球（岐阜県大 会上位チーム）レギュラー選手を対象として，視 運動刺激負荷訓練を行わずに視運動刺激負荷を行 った重心動摇検查成績と一般健康男子の訓練 2 週 後の視運動刺激負荷時の重心動摇検査成績を比較 検討した。

\section{1) 被験者}

A群：めまい平衡障害の既往がなくスポーツ 選手でない一般健康男子10名（23-25歳）である。

B群：高校野球レギュラー選手 6 名（16-17歳） である。

2）訓練方法と検査方法

a）A群は視運動刺激負荷訓練を行いその前後 で重心動摇検査を行った。訓練は前述の一般健康 男子に対する訓練と同様の方法で右回転のみ施行 した。重心動摇の記録も前述の一般健康男子と同 じ条件にて，大円筒左右方向で行い，訓練前，訓 練 2 週後に評価した。評価は視運動刺激開始 10 秒 後から30秒間の軌跡長（特に影響の大きいと考兄 られた左右方向), 左右径, 外周面積, 単位面積 軌跡長，パワースペクトルを解析した。重心動摇 （左右, 前後）とひらめ筋筋電図も前述した方法 でポリグラフ記録した。

b）B群は訓練を行わず本検查を 1 回行い，A 群と同じ重心動摇の項目を解析した。

3 ）検討項目

$\mathrm{A}$ 群とB群の成績を下記のように比較検討し た。

(1) $\mathrm{A}$ 群の訓練前後の成績とB群の成績との比較

(2) ゚ワースペクトルによるA 群の訓練前後と B 群の比較

(3)ポリグラフ記録によるA群の訓練前後と B 群 との比較

成績はノンパラメトリック検定を用いて有意差 検定を行った。

C．座位での視運動刺邀訓練による重心動摇 座位での視運動刺激のみの訓練で視運動刺激負
荷した時の重心動採に与える影響を検討した。す なわら，視運動訓練により視運動性眼振の適応の 限界が上昇することはすで報告されているが， この視運動性眼振の適応の限界の上昇が視運動刺 激負荷時の直立身体動摇に影響しているか否かる 検討した。

\section{1) 被験者}

C 群 : 座位にて視運動訓練を行った一般健康男 子7名 (24-29歳) である。

$\mathrm{D}$ 群 : 座位にて視運動訓練を行っていない一般 健康男子 7 名（26-29歳）である。

2）訓練方法と検查方法

視運動訓練は, 被験者を Ohm 型大円筒の中央 の椅子に座らせ, 頭部を固定し, 等角加速度刺激 $\left(2 \% \mathrm{sec}^{2}, 60\right.$ 秒間, 右回転) を 1 日 2 回, 3 週間連 日行った。視運動刺激時は被験者に大円筒内面の 線状をできる限り 1 本 1 本数えて追従するように 指示した。

C 群は訓練前, 訓練 1 週後, 訓練 2 週後, 訓練 3 週後に検查した。視運動訓練効果の評価とし $\tau$ ，(1)等角加速度刺激 $\left(2 \% / \mathrm{sec}^{2}\right)$ での視運動性 眼振の適応の限界を評価した。円筒速度に比べて $3 \%$ sec までの追従の遅れは正常範囲とし4), 追従 乙得た最大の円筒速度とした。(2)視運動刺激（等 角速度 $60 \%$ sec）負荷時の重心動摇検査を行い, 軌跡長 (左右方向), 左右径, 外周面積, 単位面 積軌跡長を検討した。

D群は視運動訓練を行わずに, 1 週毎に 3 週間, 同様に検査した。評価時の視運動刺激負荷による 重心動摇は前述の方法に準じて記録した。

3 ) 検討項目

C群とD群の成績を比較検討した。

\section{結 果}

A. 一般健康男子の視運動刺激負荷訓練による 重心動摇

1) 訓練の獲得の評価

a ）視運動負荷重心動摇

図 2 に成績を示した。大円筒はいずれも右回転 である。

(1)総軌跡長： 5 名中 4 名江訓練 1 週後上り, 1 名は 2 週後より娍少した。3 名は訓練 2 週後と 4 週後の差は少なかったが, 2 名は訓練 4 週後でさ らに減少した。

(2)左右径：5名中 4 名は訓練 1 週後上り, 1 名 

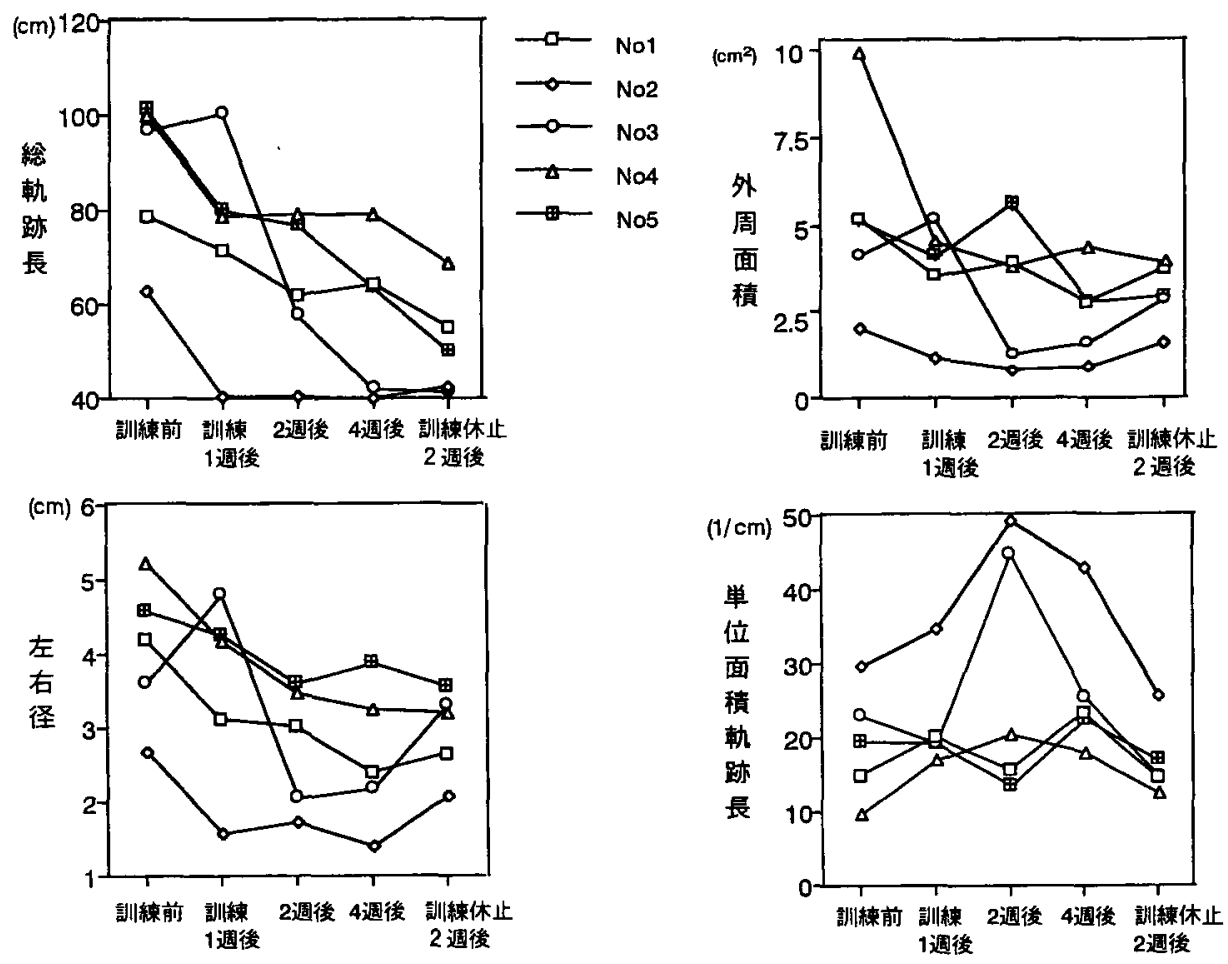

図 2 一般健康男子の視運動訓練時の重心動摇

大円筒は右回転である。総軌跡長, 左右径, 外周面積とも訓練が進むにつれ减少し, 单位面積軌跡長は増 加する傾向を認奶た。訓練休止 2 週後, 総軌跡長, 左右径, 外周面積の訓練効果は維持されたが単位面積 軌跡長は減少した。

は2 週後より減少し，2 週以後はほぼ一定した。

(3)外周面積 : 経過は一定していなかったが，訓 練 4 週後で 5 名とも訓練前より減少を認めた。

(4)単位面積軌跡長 : 訓練 4 週後で 5 名とも訓練 前より大きくなった。

b ）視運動負荷ひらめ筋活動

訓練前のひらめ筋筋電図は左右ともに筋放電の 振幅は変動が大きく不規則であった。訓練 2 週後 には左右ともに放電が持続的で安定して和り訓練 効果を認めた（図 3 )。

2 ) 訓練効果の維持の評価

a ）視運動負荷重心動摇（図 2）

(1)総軌跡長：訓練休止 2 週後も全例で訓練効果 は維持されていた。

(2)左右径: 訓練休止 2 週後も 3 名で訓練効果は 維持されていた。

(3)外周面積: 訓練休止 2 週後も訓練効果はやや 減じていたが維持されていた。
(4)単位面積軌跡長 : 訓練休止 2 週後には小さく なり訓練効果の維持は認められなかった。

b ）視運動負荷ひらめ筋活動（図 3)

訓練休止 2 週後も左右ともに放電が持続的で安 定しており訓練効果は維持されていた。

B. 高校野球選手の視運動刺激負荷による重心 動摇

1）一般健康男子の訓練前後の成績

成績を表 1 K示した。(1)軌跡長左右は，視運動 刺激之同方向（右回転）で訓練前後に有意差 $(\mathbf{p}<0.05)$ を認め, 訓練と逆方向（左回転）で も訓練前後に有意差 $(\mathbf{p}<0.05)$ を認めた。しか し逆方向では訓練効果は小さかった。(2)左右径 は, 訓練と同方向で訓練前後に有意差 $(p<0.01)$ を認め, 訓練と这方向でも訓練前後に有意差 $(\mathbf{p}<0.01)$ を認めた。(3)外周面積は, 訓練と同 方向で訓練前後に有意差 $(\mathrm{p}<0.05)$ を認め, 訓 練と逆方向でも訓練前後に有意差 $(\mathrm{p}<0.05)$ を 
認めた。(4)単位面積軌跡長は, 訓練と同方向で訓 練前後に有意差を認めず, 訓練と逆方向でも訓練 前後にて有意差を認めなかった。

2 ）一般健康男子の訓練前後の成績と高校野球

\section{訓練前}

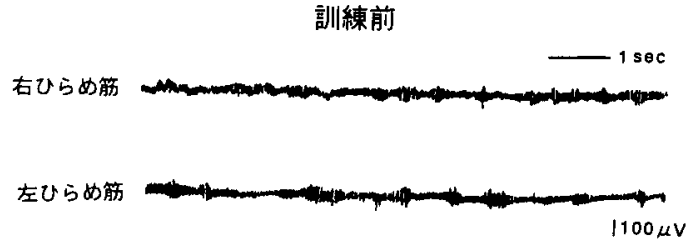

訓練 2 週後

右ひらめ筋

左ひらめ筋

訓練休止 2 週後

右ひらめ筋

左ひらめ筋

図 3 一般健康男子の視運動訓練時のひらめ等笳 電図

訓練前以筋放電の掁幅は左右とも変動が大 きく不規則であったが，訓練 2 週後より安 定した。訓練休止 2 週後も訓練効果は維持 されている。
選手の成績との比較

高校野球選手の成績は, 軌跡長左右は平均 $69.32 \mathrm{~cm}$ で健康男子の訓練前之訓練後の成績 (平 均値) の中間あたりの数值であり, 一般健康男子 の訓練後の成績と有意差を認めなかった。左右径 は平均 $3.42 \mathrm{~cm}$ で一般健康男子の訓練後より良 い成績であった。外周面積は平均 $4.40 \mathrm{~cm}^{2}$ で一 般健康男子の訓練前之訓練後の平均值の中間あた りの数值で訓練後の成績と有意差を認めなかっ た。単位面積軌跡長は平均 $17.59(1 / \mathrm{cm})$ と一般 健康男子の訓練後の成績よりも大きい数値を示し た(表 1)。

3 ) パワースペクトルルよる検討

一般健康男子は訓練前に左右方向拈上び前後方 向で 0.8-1.0 Hzにピークを認めたが，訓練後こ のパワーは減少した。代表例として一般健康男子 （24歳）の訓練前後の成績を図 4 に示した。高校 野球選手では, 訓練なしでも $0.8-1.0 \mathrm{~Hz}$ にピー クは認めず一般健康男子の訓練後の結果と類似し ていた。

4) ポリグラフ記録による検討

一般健康男子（24歳）と高校野球選手（17歳） のポリグラフ記録を比較観察すると, 高校野球選 手では視運動刺激負荷訓練をしなくても, 重心動 摇左右, 前後ともに動摇の振幅は小さく, ひらめ 筋活動も持続的で安定して㧊り，一般健康男子の 訓練後と類似した結果が観察された（図 5 )。

C. 座位での視運動刺激訓練による重心動摇

表 1 一般健康男子（A群）と高校野球選手（B群）との比較（視運動刺激負荷重心動摇）

\begin{tabular}{|c|c|c|c|c|c|}
\hline 対象 & \multicolumn{4}{|c|}{$\begin{array}{l}\text { A群 } \\
(n=10)\end{array}$} & $\begin{array}{c}\text { B群 } \\
(n=6)\end{array}$ \\
\hline 視逼動刺 & \multicolumn{2}{|c|}{ 右回転 } & \multicolumn{2}{|c|}{ 左回炂 } & 右回転 \\
\hline 重心䡃摇 & 剖唀前 & 㽤㙌後 & 唄辚前 & 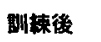 & 刜缕なし \\
\hline tho 跡唇左 $(\mathrm{cm})$ & 94.73 & 58.09 & 125.24 & 87.56 & 69.32 \\
\hline 左右径 $(\mathrm{cm})$ & 5.07 & 3.51 & 7.37 & 5.63 & 3.42 \\
\hline 外周面程 $\left(\mathrm{cm}^{2}\right)$ & 8.28 & 3.67 & $13.7 \overline{3}$ & 7.70 & 4.40 \\
\hline $\begin{array}{r}\text { 単位面皘靲跡唇 } \\
(1 / \mathrm{cm})\end{array}$ & 11.70 & 15.31 & 9.12 & 11.38 & 17.59 \\
\hline
\end{tabular}

数值は平均値を示す。 $* \mathrm{P}<0.05$ 


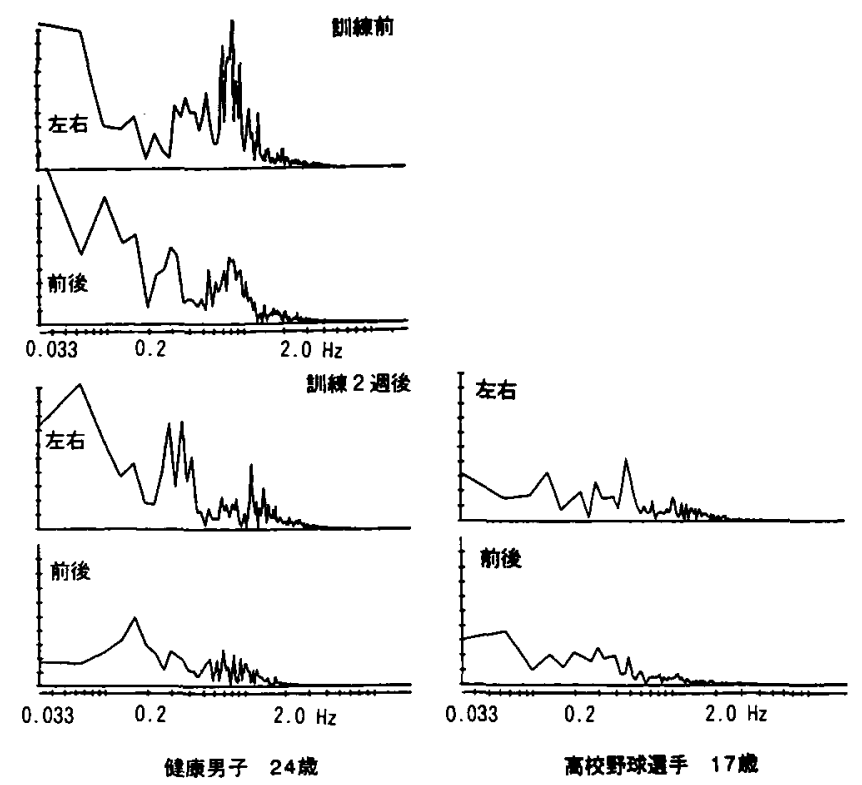

図 4 一般健康男子 (24歳) の視運動訓練前後と高校野球選手（17歳）のパワースペクトル 健康男子の訓練前に認めた 0.8-1.0 Hz のピークが訓練後には小さくなった。視運動訓練なしの高校野球 選手のパワースペクトルは一般健康男子の訓練後の成績と類似している。

1 ）視運動性眼振の OAL の検討

成績を図 6 に示した。視運動刺激訓練により全 例で OAL は上昇した。訓練と同方向で，7名の OAL の平均値は訓練前と比べて訓練 2 週後より 上昇しノンパラメトリック検定にて $1 \%$ の危険 率儿て有意差を認めた。

\section{2) 重心動摇の検討}

成績を図 7 に示した。

(1)軌跡長左右 : 視運動刺激のみの訓練 1 週後上 り 7 名中 6 名で減少し, 2 週後では全例訓練前よ り減少した。しかし，OALの上帠をよく認めた 被験者（No 1，6）で軌跡長左右に招いて必ずし も高い訓練効果（減少）は認めなかった。

(2)左右径：訓練 1 週後より 7 名中 5 名で減少 し, 2 週後では全例が訓練前より減少したが， 3 週後では 1 名が訓練前より増加した。しかし, 前 述の被験者（No 1，6）で左右径に和いても必ず しも高い訓練效果は認めなかった。

(3)外周面積：7名中 5 名で訓練 1 週後より減少 し, 2 週後では全例が， 3 週目では 6 名が訓練前 上り減少した。被験者（No 1，6）では外周面積 に招いても高い訓練効果を認めたが全体として OAL の変化と相関しているとは言い難かった。
(4)単位面積軌跡長 : 訓練によるばらつきが大き く一定した傾向を認めなかった。全体として OAL の変化と相関しているとは言い難かった。

3) 坐位にて視運動刺激訓練を行った群として いない群との比較

訓練を行ったC群では訓練前と訓練 2 週後を比 較すると, 軌跡長左右, 左右径, 外周面積はノン パラメトリック検定により有意差 $(\mathrm{p}<0.05) を$ 認めたが，訓練を行っていないD群は変化を認め なかった（図 8)。

\section{考察}

空間内での姿勢は, 視覚, 迷路, 自己受容器か らの情報と中枢神経系の関与により維持されてい る。この平衡系に刺激が加わると平衡破綻をきた すが, 平衡訓練により各受容器に強い刺激が加わ っても平衡破綻を起こしにくくなる5) 11)。ス ポーツに現われる様々な動きは反射, 予測, 精神 状態などいくつもの要素が複雑に関与して抢り, そのため運動能力を総合的に評価するのは困難で あると考觉られる。

今回, 我々は日本平衡神経科学会で「スポーツ 医学々適正検查」のワークショップ（平成 5 年〜 7 年）が催されるに当たり優れたスポーッマンを 


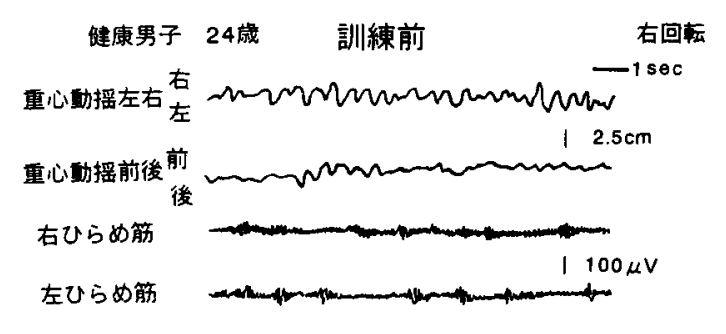

訓練 2 週後

右回転

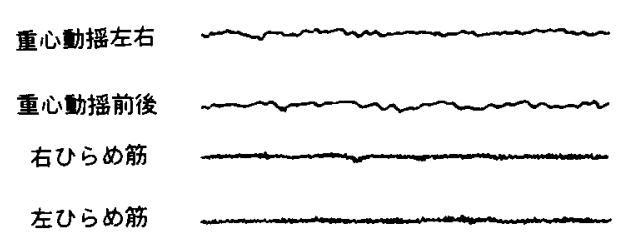

高校野球選手 17 歳右回唃

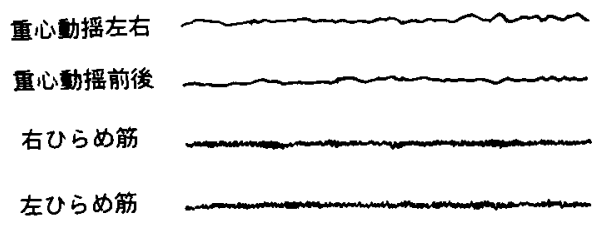

図 5 一般健康男子と高校野球選手のポリグラフ 記録

高校野球選手では視運動刺激訓練をしなく ても重心動播左右, 前後とも動播の振幅は 小さく,ひらめ筋活動も持続的で安定して いる。一般健康男子の訓練後の記録之類似 している。
見いだす評価ができないかと考光，一つの方法と して視運動刺激を外乱として負荷した時の重心動 摇検査を用いて運動能力の一面をとらえられない かを検討した。Fischer, et al ${ }^{10)}$ は視運動刺激を 与兄る時に，目と刺激線条の間に固視点を設ける と固視点のない場合に比べはるかに強いめまい感

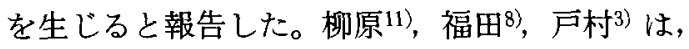
視運動負荷することにより足踏検查で偏倚が増大 することを報告している。三好12) は重心動摇に 牤いても固視点の設置は視運動刺激の影響を増大 させると報告している。今回我々も固視点を設置 して，より強い視運動刺激を負荷するようにし一 般健康男子に訓練を行った。また，視運動刺激も $60 \%$ sec と比較的速い等角速度刺激を用いた。正 常人では視運動刺激を的確に追従する速度は $40^{\circ}$ 〜 60\% /secであるといわれている13) 15)。視運動性 眼振の緩徐相速度が線条速度よりも遅れるように なるとめまいが生じるという報告12)16）向あり，

より強い刺激が加兄られると考えた。

まず，スポーッマンでない一般健康男子にこの 方法にて訓練を行い，訓練効果を検討した。視運 動負荷訓練により重心動摇の総軌跡長, 左右径, 外周面積, 単位面積軌跡長とも訓練 2 週後上り訓 練効果を認めた。そして訓練を 2 週間休止しても 総軌跡長, 左右径, 外周面積は訓綀効果の維持を 認めた。単位面積軌跡長は姿勢制御の微細さを示

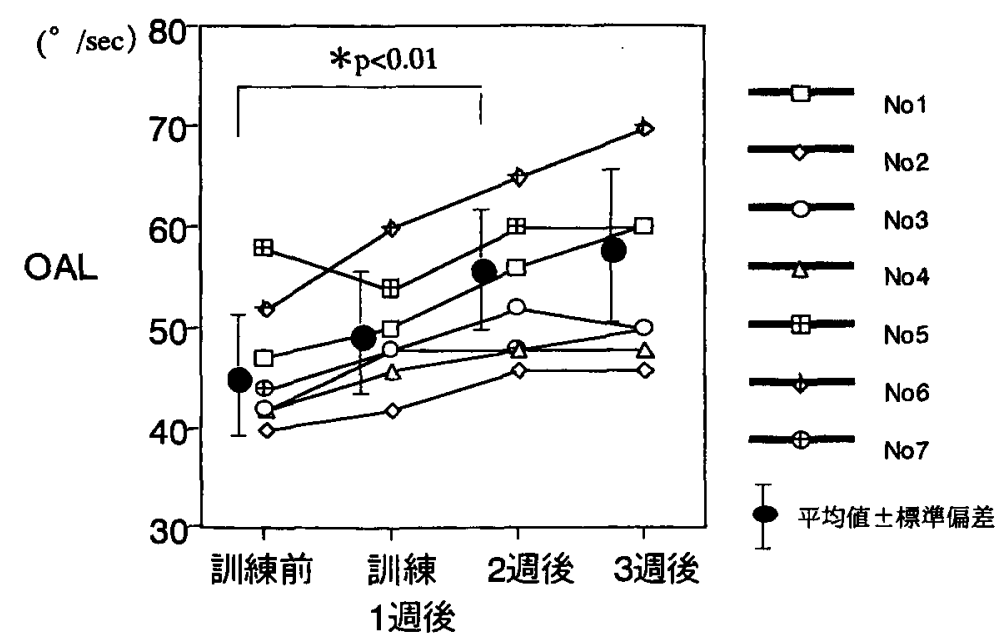

图 $6 \mathrm{OAL}$ の訓練効果

視運動訓練により全例で OAL は上昇している。平均值は訓練 2 週後より1\%の危険率で有意差を認め た。 

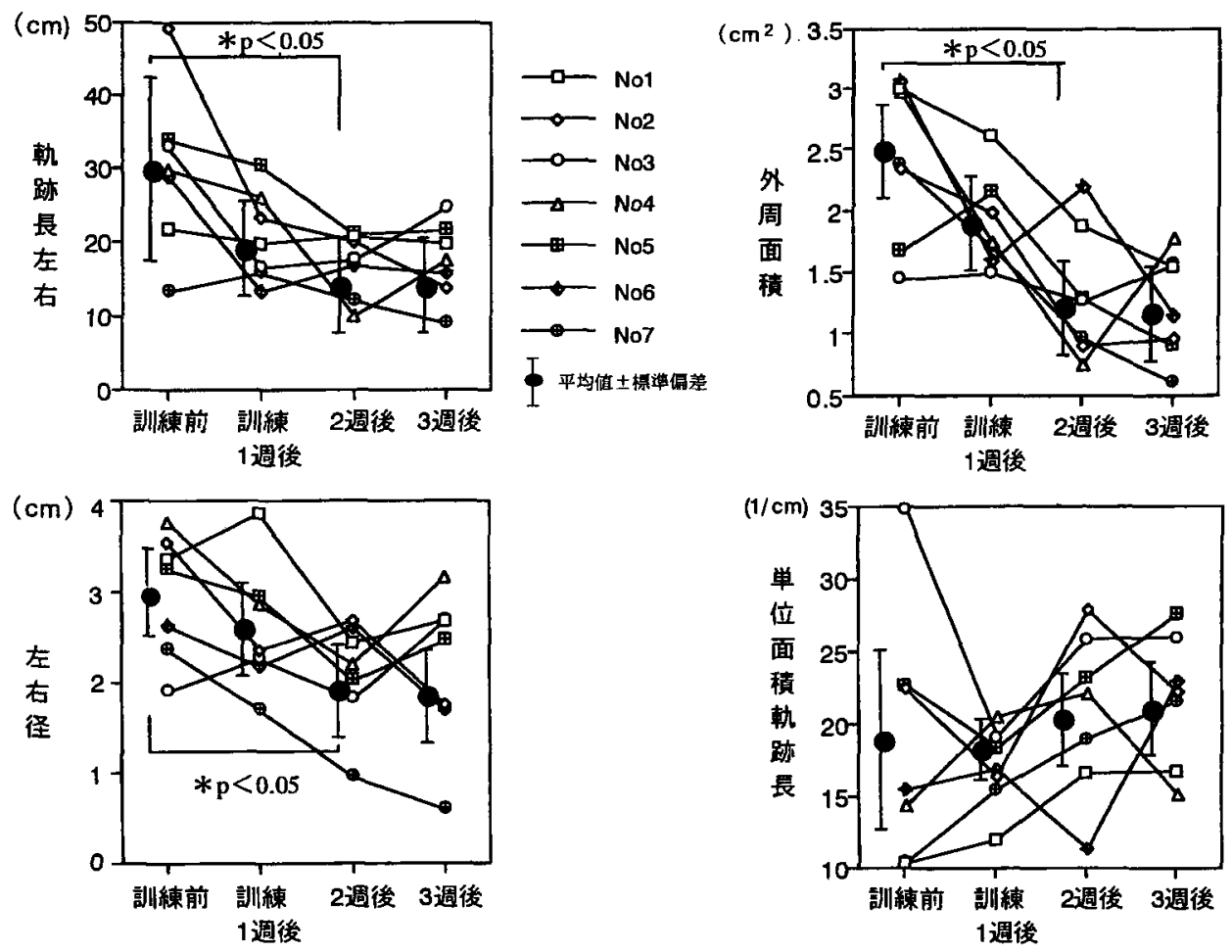

図 7 坐位による視運動訓練が視運動負荷時重心動摇検査に与える影響

軌跡長左右, 左右径, 外周面積で訓練効果を認めた。単位面積軌跡長は一定の傾向を認めなかった。
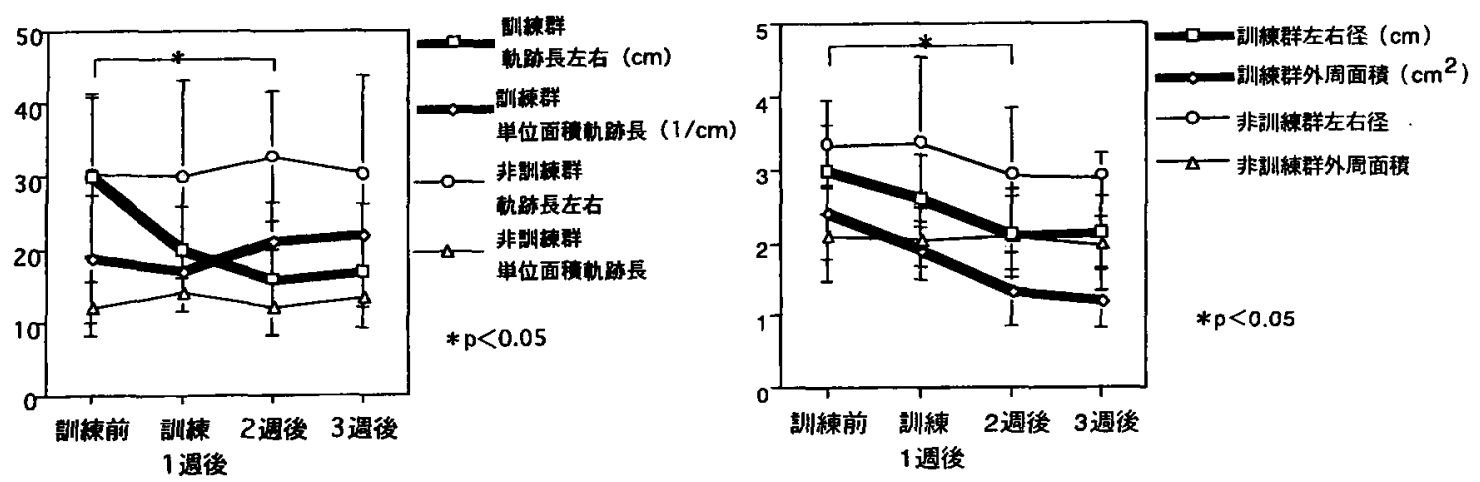

図 8 坐位による視運動訓練群と非訓練群との比較

訓練群では軌跡長左右, 左右径, 外周面積で訓練 2 週目より有意差を認めた。非訓練群では变化を認めな かった。

し，脊髄固有反射性姿勢制御を示すパラメーター といわれて㧍り，平衡訓練のパラメーターとして も有用であるとされる17) が, 訓練休止 2 週後に は, 訓練効果は維持されて扣らず，平衡訓練の敏 感なパラメーターと考えた。また，大円筒の右回
転のみの訓練でも，左回転においても軌跡長左 右, 左右径, 外周面積は有意な減少を認めた。こ れは右回転訓練の左回転への訓練効果の移し变觉 が起こったと考えられる。山田ら ${ }^{18)}$ は, 単脚直 立の訓練をすることで平衡台上の平衡維持能力の 
向上がもたらされるといら訓練獲得の移し変えを 報告して拉り，本検查に扣いても，訓練方向は逆 方向であるが，視運動刺激負荷に上る姿勢制御の 訓練といら面で類似性があることによると考学ら れた。ひらめ筋筋電図による検討でも, 訓練 2 週 後より筋放電が安定した訓練効果を認め, 外乱に 対する姿勢維持能力の向上によるものと解釈し た。

これらの結果をふまえ, 次に運動能力の高いと 思われる高校野球選手に訓練なしでこの検査を行 い, 訓練効果を認めた一般健康男子の成績と比較 検討した。この際, 視運動刺激が水平方向である ので，特に重心動摇の左右方向の軌跡長を用いて 評価することにした。高校野球選手の軌跡長左右 の平均值は, 一般健康男子の訓練前後の中間あた りの数値であった。また，視運動刺激負荷は水平 方向に加えておう，重心動摇左右径影響を及ぼ すと考えられるが，高校野球選手の左右径の平均 值は一般健康男子の訓練後の平均値よりも小さい 值であった。すなわち，高校野球選手では軌跡長 左右に比べ左右径がより小さく, 身体の安定化の ために微細な制御が行われていると考えられる。 また，単位面積軌跡長は一般健康男子の訓練前， 訓練後の值より大きな值であり, 高校野球選手の 姿勢制御の能力の良さを表わしていると考兄られ た。優れたスポーツ選手は適切に身体を摇らす能 力を身につけて和り望ましい位置にバランスをと っているといら報告 ${ }^{19)}$ がある。スポーツに拉い ては静的状態はありえず身体の摇れは絶えずあ りこの摇れの中によくコントロールされた状態 があると考えられている。すなわら高校野球の特 にレギュラー選手は微細な摇れの中に，一般健康 男子に比べ高度な姿勢制御がされていると考兄ら れた。重心動摇のパワースペクトルを検討する と, 一般健康男子の訓練前では $0.8-1.0 \mathrm{~Hz}$ K ピークを認め視運動刺激負荷でこの周波数のパ ワーが増大していることが観察でさる。訓練後に はこのパワーは消失しており訓練効果と考えられ た。高校野球選手では特定のピークは認めず一般 健康男子の訓練後のパワースペクトルと類似して いた。ポリグラフ記録に括いても，一般健康男子 の訓練後の成績は左右動摇の振幅が著明に減少 し, 訓練により平衡失調が起こり難くなったと考 完られる。高校野球選手も左右動摇の振幅は小さ
く安定していた。ひらめ筋筋電困では高校野球選 手の筋活動は視運動刺激負荷訓練を行っていない にもかかわらず，両側ひらめ筋ともに放電が持続 的で安定した結果を示しており，普段の練習が自 己受容性姿勢制御系の訓練や視運動刺激負荷訓練 となっていると思われる。スポーッ選手の中で特 に球技選手の OAL が高いことは知られている2)。 戸村3) は大円筒内にオトゴニオメーターといら固 視点を設けた足踏検查に打いて OAL 以下の視運 動刺激に対して刺激が大きくなるに従い偏位が大 きくなると報告している。今回は座位による視運 動訓練で OAL が上后しているにもかかわらず， 重心動摇は訓練前より安定していた。訓練で起こ る各平衡器官の機能の連係についての報告20)を 考えると, 視器の訓練により各平衡器官の間で訓 練効果の影響を認めたといえるかもしれない。し かし今回の検討では，OALの上昇と視運動負荷 重心動摇検査の結果の相関俚明らかではなかっ た。OAL が高く，単位面積軌跡長が大きい高校 野球選手で重心動摇が安定していることを考学併 せると, 視運動刺激の反復, 自己受容器の訓練お よび前庭への刺激（毎日の訓練）は各平衡器官が 相互に連係しつつ平衡と運動能力を高め, 外乱に 対しても不安定な身体動摇の発現を起こりにくく していると考えられた。

以上, 高校野球選手は視運動刺激といら外乱に 対する姿勢制御といら点で優れた能力をもってい ることが観察できた。

視運動刺激負荷重心動摇検查で左右径, 単位面 積軌跡長を指標に運動能力の評価を行える可能性 があると考えられた。今後, 運動能力レベル別の 検討, 何か一つのスポーツを始める時から経時的 に本検查を行い，スポーツの資質の将来性をみる ことができないか検討寸ることが課題である。

\section{まとめ}

優れたスポーッマンを見いだすために，視運動 刺激負荷重心動摇検査を用いて検討した。

1.一般健康男子では, 視運動刺激負荷訓練 2 週後より重心動摇の総軌跡長, 外周面積, 左右 径, 単位面積軌跡長ともに訓練効果を認めた。訓 練休止 2 週後も訓練効果の維持を認めた。パワー スペクトルは, 訓練前の $0.8-1.0 \mathrm{~Hz}$ に認めた ピークが訓練により減少した。ポリグラフ記録で は重心動摇左右, 前後とも訓練により動摇の振幅 
は減少した。ひらめ筋活動も訓練により不規則な 放電は減少し安定した。

2. 高校野球レギュラー選手は視運動刺激負荷 訓練なしでも，左右径，単位面積軌跡長，パワー スペクトル，ひらめ筋活動とも訓練した一般健康 男子と同じ様な成績を示した。

3. 座位での視運動訓練により視運動性眼振の 適応の限界の上昇を認め, 同時に視運動刺激とい ら外乱に対して重心動摇は安定した。

4. 本検査における重心動摇の左右径, 単位面 積軌跡長は運動能力の評価に有用であると考兄ら れた。

本論文の要旨は，第96回日本耳鼻咽喉科学会総 会, 第53回，第54回日本平衡神経科学会総会, 第 2 回, 第 3 回スポーツ医学々適性挨査のワークシ ョップにおいてロ演した。な执，本研究は文部省 科学研究費（C）の補助金（番号：07671848）に より行われた。

\section{文 献}

1) Hoshino T: Vestibulare Reflex bewegungen des Auges beim Kaninchen. Acta Otolaryngol (Stockh) 4: 328-338, 1921

2) 時田 喬 : 電気眼振図の分析. 臨床 $\mathrm{ME} \cdot$ 新 しい診療 8: 13-18, 1984

3）戸村義則：視運動瓷䯣反射の検討. 耳鼻臨床 $77: 196-218,1984$

4 ）菱田 登：小脳障害例の視運動眼振. 耳鼻臨 床 47: 910-926, 1954

5 ）星野貞次, 福田 精, 岡田三郎, 他：特殊な る回転訓練を施せる学童の回転性後眼振につ いて.耳鼻臨床 47: 769-775, 1954

6 ) 岡田三郎：回転後眼振低減の観察.耳鼻臨床 47: $776-797,1954$

7 ）前田正明：乳児の平衡機能とその訓練. 耳鼻 臨床 7: 798-803, 1954

8 ）福田 精：訓練の生理. 運動と平衡の反射生 理. 85-113頁, 医学書院, 東京, 1957

9) 時田 喬 : 視運動眼振と迷路眼振. 眼振の生 理と検查. 20-26頁, 金原出版, 東京, 1973
10) Fischer $M H$, Veits $C$ : Über optokinetische ausgelöste Körperreflexe beim Menschen. Pflugers Arch Gesamte Physiol Menschen Tiere 219: 579-587, 1927

11）柳原亮一：視性運動失調並びに視性眩量の研 究. 耳鼻臨床 45: 47-55, 1952

12）三好豊二：体平衡と各種視運動性刺激の関 係. 耳鼻臨床 76: 538-547, 1983

13) Miyoshi T, Pfaltz CR: Studies on the correlation between optokinetic stimulus and induced nystagmus. ORL 35: 350-362, 1973

14）時田 喬, 宮田英雄, 藤垣 熙, 他：視機性 眼振異常ととの解釈. 耳鼻臨床 62: 923-953, 1969

15）玉田 彰, 桶渡章二, 三好豊二：視標追跡運 動比打付る速度, 振幅, 周波数の及汪す影響 力について. Equilibrium Res 40:38-44, 1981

16) Witkin HA, Wapner S: Visual factor in the maintainance of upright posture. Am J Phychol 63: 31-39, 1950

17）大川 剛, 時田 喬, 柴田康成, 他 : 重心動 摇検査一単位面積軌跡長の意義一健常者に特 ける検討. Equilibrium Res 54:296-306, 1995

18）山田剛寛, 大野通敏, 白戸弘道, 他：熟練の 平衡生理学的研究一平衡台に括讨る直立姿勢 維持に和いて一. Equilibrium Res 52: 225236, 1993

19) Bohmer D, Herwig H: スポーツにおけるバ ランスの重要性. 臨床スポーツ医学. 1-9 頁, 文光堂, 東京, 1991

20）檜學 : 訓練で起こる各平衡器官の機能の 連係. めまいの科学. 65-68頁, 朝倉書店, 東京, 1992

$$
\left(\begin{array}{l}
\text { 原稿到着: 平成 } 9 \text { 年 } 2 \text { 月 } 14 \text { 日 } \\
\text { 別刷請求先 : 加藤雅也 } \\
\overline{\mathbf{T}} 500 \text { 岐阜市司町 } 40 \\
\text { 岐阜大学医学部耳鼻咽喉科学教室 }
\end{array}\right)
$$

